\title{
Z-Score Application for Jordanian Islamic Banks
}

\author{
Yazan Qasim \\ The university: Virginia Commonwealth University \\ Banking and finance, USA
}

Received: Jan. 28, 2020 Accepted: Feb. 27, 2020 Online published: Mar. 11, 2020

doi:10.5296/jpag.v10i1.16335 URL: https://doi.org/10.5296/jpag.v10i1.16335

\begin{abstract}
This research primarily aims to utilise the Altman model of Z-score to examine the trend performance and predict bankruptcy among three Islamic banks in Jordan for the period of 2010-2016. Furthermore, it also aims to introduce the Z-score model as a beneficial diagnostic technique for possible causes standing behind the bank performance crises. The results of the Z-score model showed that the Jordan Dubai Islamic Bank (JDIB), Jordan Islamic Bank for Finance and Investment (JIBFI), and International Islamic Arabic Banks (IIAB) recorded safe zones in the period of study except for JDIB and IIAB which recorded a Grey zone in 2010, 2011, and 2012 and 2010, 2011, 2012, and 2013, respectively. The implication of this research is important to policymakers, managers, and investors who can use the information to monitor the safest bank among these three Islamic banks in Jordan based on the priority for lending that has to be done in the order of JIBFI, JDIB, and then IIAB. On the other hand, the Z-score was found to be a valid model to examine performance, and ratios utilised in computing the Z-score which was considered to provide workable instrumental indicators as well as being adopted to finance short-term and long-term projects by Jordanian Islamic banks.
\end{abstract}

Keywords: Islamic bank, Z-score, bankruptcy, risk management, finance

\section{Introduction}

Looking into the economic situation nowadays, bank sectors are considered a critical part of the financial system. Hence, banks play a significant role in economic growth and development. Thus, a lot of studies have been conducted to assess the performance of banks worldwide. The Z-Score model has been utilised as a method to examine the performance credibility of Jordanian Islamic banks. This paper provides the Z-score value for three Islamic banks in Jordan; JIBFI, IIAB, and JDIB. This value is useful when these banks demand fundamental finance from the Central Bank Jordan (CBJ) or any other finance agency. The output in this study may be considered as an alarm to any future monetary distress which Jordanian Islamic banks may face. 
The importance of this research arises from its attempt to examine the distance to default by using the weighted average Z-score for Jordanian Islamic banks. The study could be the first that applies Z-score to developed country markets like Jordan. Jordanian financial market is characterised by high-risk profiles compared to traditional banks for the following reasons;

a) The absence of hedging instruments against fluctuations in foreign currency exchange rates exposes Jordanian Islamic banks to foreign exchange risks.

b) The financial regulation reform by the Jordanian government (deregulation) exposes the Islamic Bank (IB) to risks with regards to the Islamic Banks' investment in profit and loss sharing.

c) Differences in returns on profit and loss sharing investments among Jordanian Islamic banks have effects on liquidity management.

d) A large percentage of liquid assets expose Jordanian Islamic banks to liquidity risk (Muhammed, 2004).

e) The impending financial crisis shown in the financial reports of the World Bank Group in 2016 indicated that the government of Jordan has to pay US $\$ 37,000,000,000$ as a total debt to the World Bank. An increase of these debts could affect on the economic sectors. Indeed, Jordanian Islamic banks may be facing bankruptcy as the legal financial and personal far-reaching consequences (harm to the banks' reputation and business relationships, and trouble in getting credit later on) and effects on the owners, policymakers, managers, and employees. Besides, owners may utilise this information to take corrective decisions to prevent financial failure. However, to improve the performance of the Islamic banks in Jordan, policymakers should plan the right decision to avoid any financial stress or failures and find a significant solution for any predicted problems. The main aim of this research is to implement the "Z-score" to measure the performance trend and predict bankruptcy over the period of 2010-2016. The literature review of this study introduces some of the Z-score results from previous research, followed by a description of the methodology, data analysis, and conclusions and the future works at the end.

\section{Literature Review}

Z-score which was first applied in 1968 by Altman is a useful model for measuring financial performance and predicting the bankruptcy of firms. The study measured the effectiveness of the Z-score. Thynne (2006) and Taffler (2011) showed that the model has 70\%-80\% reliability and identified it as a robust technique. The Z-score is a valid model to examine the performance of Islamic banks and the ratios used in calculating Z-score may be considered to give workable indicators. A lot of studies have been conducted to examine the performance and predicting bankruptcy by utilising Z-score as a tool (Keige, 1991; O'Leary, 2001; Argenti, 2003; Aldrich \& Nelson, 2007; Eidleman, 2007; Saif \& Al-Zaabi, 2011; Pradhan, 2014).

Abidali and Harris (1995) took 20 non-failed and 11 failed companies which utilised the modified Z-score to predict failure. They clarified that the results of the balance sheet information were not enough to predict failure; thus, they identified the occurring 
management characteristics of the failed companies including preservation of a position of sole authority or autocratic chief executive, the same person as both chief executive and chairman, non-arbitrative members on the company board, limit of strong financial directors sharing responsibility for decision-making, lack of engineering skills, poor personal skills, defective managerial skills, limit of financial control, legal skills or inadequate marketing, cash flow plan and incomplete accountancy system, poor budgetary control system, and poor marketing. They briefed that the acknowledgment of previous management action is highly crucial as all the failed companies appeared to record negative Z-scores for various years prior to failure. Hence, the lower Z-scores for the company, the more years the company is considered as at risk and the more probable it is that the company will fail. Thence, the Z-score can be utilised to express the companies' rank in terms of solvency.

Abidali and Harris's findings fell in line with Sauer (2002) who accused that utilising Z-score for consecutive years of companies' accounts may highlight that the companies' financial condition is declining. Sauer announced that $\mathrm{Z}$-score is an early alarm procedure designed to give more time to the operation manager to look at matters involving budgeting, adjusting firm strategy, marketing, production, shipping, and debt collecting before the financial crisis, as appeared in Saudin and Proporato's (2007) study who predicted the bankruptcy of a number of companies listed on the Buenos Aires stock exchange in 1990. O'Leary (2001) argued that prediction of bankruptcy is one of the most important business decision-making problems affecting the entire lifespan of a business; failure results in a high cost of the collaborators, organisations and firms, country's economy, and the society (Ahn et. al, 2000).

Rahmat (2002) applied the Z-Score model to investigate the financial performance of Indonesian banks over a period (1995-1997) before they were announced bankrupt by Bank Indonesia. Christopoulos et al. (2009) utilised the Altman model to predict the probability of bankruptcy and inferred that the Altman model was shown to be capable of and accurately identify samples of corporate financial difficulties. Altman demonstrated that it was more helpful than financial ratio analysis. Some studies, particularly those conducted in the banking industries have inferred that the Altman Z-Score model \{first model and last revised model $\}$ is less suitable when it is utilised to evaluate the performance of both commercial and Islamic banks (Rahmat 2002, Endri 2009).

Karim et al. (2018) conducted a study to analyse the stability of 50 conventional and Islamic banks in Malaysia. They utilised two Z-score tools and CAMEL variables during a period (1999-2015). The results indicated that the banks were ranked favourably in overall average bank stability score, sensitivity to market risk, asset quality, earnings, and profits. However, the conventional banks were recorded with favourable ranking in liquidity, sensitivity to market risk, earning, and profitability.

In spite of the differences in the components of financial statements between Islamic Banks (IBs) and Conventional Banks (CBs), Saif and Al-Zaabi (2011) implemented the Emerging Market (EM) and Z-score model to forecast insolvency and bankruptcy so as to estimate the performance of major IBs in the United Arab Emirate (UAE) The Z-score model was proposed and introduced in this industry as a useful diagnostic tool for potential causes of 
worsening financial performance. The study used the Z-score model for EMs set by Altman, in which it was required to verify that the Z-score has more than $80 \%$ accuracy and reaffirm that it is a strong tool that could be utilised to calculate the probabilities of the firm distress. The approach used in this study was to seek out the financial statements of the IBs in UAE. The EM Z-scores of the selected firms were gathered for the past three years in distinction to the current year's score. The research found that IBs in the UAE need to work on improving all ratios to suppress their scores and gain a superior understanding of their previous performance in order to comprehend their current condition in the industry. Therefore, Z-score can be adopted by the IBs in the UAE as an effective assessment tool aiming at financing potentially long-standing partnership projects as well as small and medium enterprises. The Z-score model needs to be adopted by IBs with different credit risk analysis approaches to estimate the competencies and sustainability of potential projects in Islamic banks.

Generally, a financially sound and healthy Z-score is a useful tool that can be adopted by Islamic banks together with other financial analysis methods to calculate the Islamic banks' industry average based on different indicators. The study of the ratios utilised in estimating the Z-score could be considered in preparing the indicators. The Z-score model is a sufficient model to estimate the performance of IBs. It can be used in deciding whether or not to finance long-term partnership projects and SMEs. The restrictions, however, is that the Islamic banking industry is still seen as a small industry that may have harmful consequences on the study results.

\section{Methodology}

The methodology adopted was based on previous studies, for example, Parashar (2000) and Altman (2002) which preserved that Z-score has more than $80 \%$ accuracy. The previous studies also identified that it is helpful in measuring the trend performance and prediction of a potential distress of firms since they include a number of financial ratios that may be utilised to predict company crises, solvency, and corporate bankruptcy. The basic ratios were obtained from details mentioned in financial statements such as the balance sheet, cash flow, annual details of the banks, and profit-loss statements. These data were derived from the official websites of the Jordanian Islamic banks and financial institutions. Consequently, the approach utilised in this research was to assess financial statements as an effort to assess the performance of Islamic banks in Jordan by computing the Z-score as developed by Altman (2002) for the period of 2010-2016.

* The following Z-Score formula was utilised in this research.

Z-score $=6.56 * \mathrm{X} 1+3.26 * \mathrm{X} 2+6.72 \mathrm{X} 3+1.05 * \mathrm{X} 4$

The zones of discrimination depend on formula 1 result.

Z-score > 2.6 "safe" zone

$1.1<$ Z-score $<2.6$ "Grey" zone

Z-score $<1.1$ "Distress" zone 
* The definitions of the variables are as follows;

X1. Current ratio (i.e. Working Capital) to Total Assets = (current Assets-Current Liabilities) / Total Assets.

X2. Retained Earnings / Total Assets.

X3. Return on Total Assets $($ ROTA $)=$ Earnings before Interest and Taxes $($ EBIT) / Total Assets.

X4. Market Value of Equity (i.e. Net Worth) = Equity / Total Liabilities.

\section{Results and Discussion}

Market capitalisation proposed that banks are predominantly capturing markets. In this paper, three Jordanian Islamic banks were selected for applying Z-score. These banks are Jordan Dubai Islamic Bank (JDIB), Jordan Islamic Bank for Finance and Investment (JIBFI), and International Islamic Arabic Bank (IIAB) of Jordan. The essential input tables for all the internal parameters were formulated for the three Islamic banks in Jordan. The process of input ratio utilised the book formulae for calculating ratios. The details of the Z-score values and internal ratios for Jordanian Islamic banks for the period of 2010-2016 are listed in the following tables.

Table 1. Internal ratios for JDIB for the period of 2010-2016

\begin{tabular}{|l|l|l|l|l|l|l|l|}
\hline $\begin{array}{l}\text { Fiscal } \\
\text { year }\end{array}$ & 2010 & 2011 & 2012 & 2013 & 2014 & 2015 & 2016 \\
\hline $\mathrm{X} 1$ & .2869705 & .223314 & 0.1925361 & .3704266 & 0.9230226 & .9409663 & .9508449 \\
\hline $\mathrm{X} 2$ & -.0035164 & .0106716 & .0121319 & .013281 & .0131827 & .00573 & .0110181 \\
\hline $\mathrm{X} 3$ & -.0166604 & .0143493 & .0017190 & .0041867 & .0041624 & .0062 & .0096685 \\
\hline $\mathrm{X} 4$ & .6944523 & .4888443 & .3649481 & .3239785 & 1.1836736 & 1.1300042 & 1.0225732 \\
\hline
\end{tabular}

Table 2. Internal ratios for JIBFI for the period of 2010-2016

\begin{tabular}{|l|l|l|l|l|l|l|l|}
\hline $\begin{array}{l}\text { Fiscal } \\
\text { year }\end{array}$ & 2010 & 2011 & 2012 & 2013 & 2014 & 2015 & 2016 \\
\hline $\mathrm{X} 1$ & .8647282 & .8601795 & .8411560 & .8364487 & .9673650 & .9668288 & .9678099 \\
\hline $\mathrm{X} 2$ & .0125315 & .0050763 & .0117737 & .0149324 & .0145817 & .0166179 & 0189348 \\
\hline $\mathrm{X} 3$ & .0158382 & .0137333 & .0169711 & .0197303 & .0180112 & .0196787 & .0204479 \\
\hline $\mathrm{X} 4$ & .080348 & .0768648 & .0819328 & .0844443 & .255013 & .2569612 & .2626342 \\
\hline
\end{tabular}


Table 3. Internal ratios for IIAB for the period of 2010-2016

\begin{tabular}{|l|l|l|l|l|l|l|l|}
\hline $\begin{array}{l}\text { Fiscal } \\
\text { year }\end{array}$ & 2010 & 2011 & 2012 & 2013 & 2014 & 2015 & 2016 \\
\hline $\mathrm{X} 1$ & .3076093 & .1959227 & .1988883 & .188803 & .617185 & .6232971 & .6002455 \\
\hline $\mathrm{X} 2$ & -.0248617 & -.02309 & -.0144428 & -.0025272 & .0014281 & .005135 & .009562 \\
\hline $\mathrm{X} 3$ & .0092502 & .013504 & .014074 & .0167527 & .012185 & .013842 & .017599 \\
\hline $\mathrm{X} 4$ & .0866507 & .086889 & .094106 & .228438 & .216139 & .202946 & .196111 \\
\hline
\end{tabular}

Table 4. Z-score ${ }^{1}$ values for Jordanian Islamic banks for the period of 2010-2016

\begin{tabular}{|l|l|l|l|l|l|l|l|}
\hline Banks & 2010 & 2011 & 2012 & 2013 & 2014 & 2015 & 2016 \\
\hline JDIB & 2.48828 & 2.10944 & 1.69733 & 2.84160 & 7.36883 & 7.41960 & 7.41213 \\
\hline JIBFI & 5.904268 & 5.832322 & 5.756441 & 5.757038 & 6.7822504 & 6.798622 & 6.823736 \\
\hline IIAB & 2.090013 & 1.391963 & 1.451015 & 1.582748 & 4.362226 & 4.411683 & 4.292969 \\
\hline
\end{tabular}

Table 4 introduces the details of the Z-score and shows the differences among these banks. The $\mathrm{Z}$ values of JDIB in 2010, 2011, and 2012 were in the Grey zones, while for the period of 2013-2016, the $Z$ values were in the safe zones and it was instability that changes $Z$ values then they increase sharply as shown in Figure 1. On the other hand, JIBFI $Z$ values were in the safe zones for the period of 2010-2016 and changed slightly as appeared in Figure 1. The $Z$ values of IIAB were in the Grey zones for the period 2010-2013, while in 2014, 2015, and 2016, the Z values were in the safe zones and its instability changed as appeared in Figure 1. Depending on the result of three banks over 2014-2016, the $Z$ values revealed that it was safe to lend to the three banks as the $Z$ values obtained fell on the safe zone. Figure 1 explains the variations in Z-score zones among the three Jordanian Islamic banks for the period of 2010-2016.

${ }^{1} \mathrm{Z}$-score value $=6.56 * \mathrm{X} 1+3.26 * \mathrm{X} 2+6.72 \mathrm{X} 3+1.05 * \mathrm{X} 4$ 

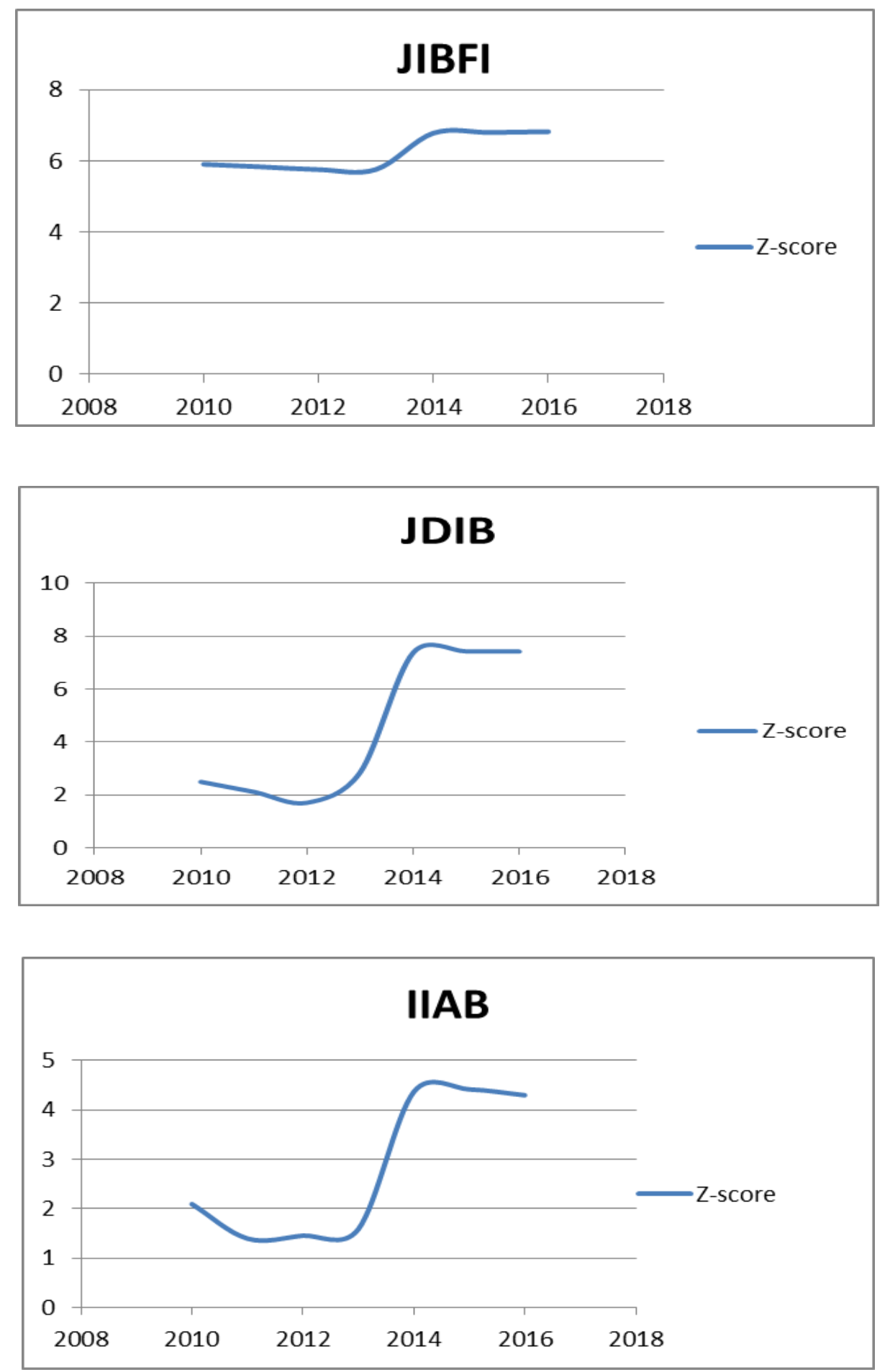

Figure 1. Changes in Z values of Jordanian Islamic banks for the period of 2010-2016

\section{Conclusion and Future Works}

The analytical results indicated that the $\mathrm{Z}$ value of JIBFI was the highest among these three banks. Priority lending was in the order of JIBFI, JDIB, and IIAB. Overall, Jordanian Islamic banks have a stable and progressive improvement from 2013 onwards. From the previous analysis, there are different combinations of long-term and short-term debts as a proxy for a company's liabilities used to investigate if the liquidity constraint from short-term liabilities 
alone actually pushes the company to declare bankruptcy or we have to consider that the amount of long-term debts is also related to the possibility of determining a company's bankruptcy. This investigation exhibited that the Z-score is a beneficial technique that may be formulated by Jordanian Islamic banks to supplement banks with other financial analytical techniques to create Islamic banks' industry averages. The investigation also found that the ratios utilised in the computation of Z-score gave profitable instrumental indicators. Finally, it is better for Jordanian Islamic banks to comprehend and compare their previous performance with the latest performance and realise their financial position in the industry. Thus, Jordanian Islamic banks should take a shot at enhancing the ratios that are towing their scores down. Future studies are required towards refreshing the coefficient values associated with every ratio in Z-score model as per the inputs from the Jordanian Islamic banking industry. However, the decline of Z-Score has to spur researchers to conduct more in-depth analysis to seek out the root causes.

\section{References}

Abidali, A. F., \& Harris, F. (1995). A methodology for predicting company failure in the construction industry. Construction Management and Economies, 13(3), 189-196. https://doi.org/10.1080/01446199500000023

Acosta-González, E., \& Fernández-Rodríguez, F. (2014). Forecasting financial failure of firms via genetic algorithms. Computational Economics, 43(2), 133-157.

Ahn, B. S., Cho, S. S., \& Kim, C. Y. (2000). The integrated methodology of rough set theory and artificial neural network for business failure prediction. Expert systems with applications, $18(2), 65-74$.

Aldrich J. H., \& Nelson F. D. (2007). Linear probability, logit and probit models Sage Beverly Hills. Calif.

Altman, E. I. (2002). Corporate distress prediction model in a turbulent economic and Basel II environment. Available at: www.pages.stern.nyu.edu/,ealtman/ (accessed 24 May 2008).

Argenti, M. (2003). Financial Ratios as Predictors of Failure. Empirical Research in Accounting: Selected Studies. The University of Chicago, 71-111.

Christopoulos A. G., Gerantonis, N., \& dan Vergos, K. (2009). Can Altman Z-score Models Predict Business Failures in Greece. Research Journal of International Studies-Issue 12: October, 21-28.

Eidleman, E. B. (2007). A discriminant analysis of predictors of business failure Journal of Accounting Research. Institute of Professional Accounting, Chicago, 167-179.

Karim, N. A., Alhabshi, S. M. S. J., Kassim, S., \& Haron, R. (2018). Measuring Bank Stability: A Comparative Analysis of Islamic and Conventional Banks in Malaysia. In Proceedings of the 2nd Advances in Business Research International Conference. Springer, Singapore, pp. 169-177. https://doi.org/10.1007/978-981-10-6053-3_16

Keige. P. (1991). Business Failure Prediction Using Discriminate Analysis. The University of 
Nairobi.

Muhammed, O. (2004). Capital Adequacy Norms for Islamic Financial Institutions. Available at: www.islamic-finance.net. (accessed 24 May 2008).

O'Leary, E. G. (2001). Business Failure Prediction and the Efficient Market Hypothesis. Simon Fraser University.

Parashar, S. P. (2000). Z score of UAE companies. Emirates Institute for Banking and Financial Studies. Research Paper.

Pradhan, R. (2014). Z score estimation for Indian banking sector. International journal of trade, economics, and finance, 5(6), 516. https://doi.org/10.7763/IJTEF.2014.V5.425

Rahmat, T. (2002). Penerapan Z Score Untuk Memprediksi Kesulitan Keuangan Dan Kebangkrutan Perbankan Indonesia (Studi Kasus Kebijaksanaan Bank Indonesia Tanggal 13 Maret 1999 terhadap 18 Bank Publik). Jurnal Manajemen Investasi dan Portofolio. diakses melalui: www.geocities.com/rahmatov/Z-Score.

Saif, H., \& Al Zaabi, O. (2011). Potential for the application of emerging market Z-score in UAE Islamic banks. International Journal of Islamic and Middle Eastern Finance and Management, 4(2), 158-173. https://doi.org/10.1108/17538391111144498

Saudin, A. R., \& Proporato, M. (2007). Corporate bankruptcy prediction model applied to emerging economies: evidence from Argentina in the Years 1991-1998. International Journal of Commerce \& Management, 17(4), 295-311. https://doi.org/10.1108/10569210710844372

Sauer, T. G. (2002). How may we predict bankruptcy. CCE. Business Credit Selected Topic, 16-17.

Taffler, C. (2011). Alternative financial ratios as predictors of failure. Accounting Review, XLIII, 113-122.

Thynne, K. (2006). Test of the generalizability of Altman's bankruptcy: Prediction model. Journal of Business Research, 53-61.

\section{Copyright Disclaimer}

Copyright for this article is retained by the author(s), with first publication rights granted to the journal.

This is an open-access article distributed under the terms and conditions of the Creative Commons Attribution license (http://creativecommons.org/licenses/by/4.0/). 